\title{
Construction of Elementary Schools in Galicia and the Kingdom of Poland in Magazines of the late 19th and Early 20th Centuries
}

\begin{abstract}
Among the numerous pieces of information pertaining to the social life of the population of the Kingdom of Poland and Galicia a number of notes and articles about the necessity to undertake the construction of schools were published. The authors would frequently mention the outrageous conditions in which children were forced to study, the lack of flats for teachers, and the failure to follow the rules of hygiene in schools. It was argued that combating illiteracy could bring positive results by securing the proper conditions for raising and educating all school-age children. Discussions in the press covered examples of local initiatives aimed at building schools, as well as ways of making the local communities of villages and towns more active.
\end{abstract}

Keywords: people's school, construction of schools

The intensive development of new means of communication, such as telegraphs and magazines, in the second half of the 19th century means that a range of information from the world and the country can be delivered. The ever-increasing interest in life issues means that magazines try to "satisfy the curiosity and ever-increasing desire for current news, growing with the development of urban-industrial life, by trying to publish a body of news so large that a person who reads very little nothing, apart from their daily newspapers, can ingest in their entire lifetime ${ }^{1}$." Columns, letters, notes, reviews, articles or reports are testimonies of interesting events and issues that occupied the society at the turn of the 19th and 20th centuries.

Among the many topics, which can be found in the press of Galicia and the Kingdom of Poland published at that time, school and educational issues occupy a prominent place.

\footnotetext{
${ }^{1}$ KUCHARZEWSKI, J., Czasopiśmiennictwo polskie wieku XIX w Królestwie, na Litwie i Rusi oraz na emigracji, Warsaw, 1911, p. 88.
} 
Their diversity is proof of interest in school issues. They served not only as information for the readers, as they were also aimed at promoting numerous educational issues and drumming up social support among children and adults alike.

When analysing periodicals published in Galicia and the Kingdom of Poland starting in the 1860s, I decided to devote particular attention to issues connected with the construction of school buildings, especially folk and elementary schools. In my research plans, this topic is the initial stage of a broader project, which will include the construction of elementary public schools in the Second Republic of Poland in the school districts of the former Russian (Vilnius and Grodno provinces) and Austro-Hungarian (Galicia) partitions.

In Galicia, the need to build folk schools was voiced primarily in the local press. Articles provided information about the technical and hygienic condition of existing buildings and pointed out the possibilities of solving the issues, which were so important for children's education.

In 1864, the Warsaw press stated that "in the Przasnysz district (Austrian Galicia), the Dobrzany municipality undertook to build a school building with a teacher's apartment and make school equipment from wood promised by local landowner, keeping them in good shape, for the purposes of conducting regular school education ${ }^{2}$." However, no further information is available as to whether the project was in fact completed.

According to Bolesław Baranowski, "the state of folk education, as noted by the National School Council in 1868, required extraordinary efforts on the part of the authorities and the country. The first and most important concern was to address the widespread issue of illiteracy as quickly as possible and, for that purpose, cover the country with a dense network of folk schools ${ }^{3}$." It was not an easy task because, as the author points out, there was a lack of capital in the country, and therefore it was necessary to use modest buildings and unsatisfactory equipment. Baranowski also wrote: "In 1874, 2429 schools located in their own buildings, and 198 in leased ones, were registered. According to the lists, 805 buildings were in good condition, 998 in moderate condition and 824 in poor condition ${ }^{4}$." However, the National School Council pointed out that even buildings described as "in good condition" did not correspond to the Council-specified teaching and hygiene condition guidelines. Further descriptions of the working conditions of folk schools in Galicia paint a gloomy picture of the reality of contemporary school: poor technical condition of buildings, as well as small and dark classrooms furnished with tables illsuited to the children's height, prevented a proper organisation of the school day. "In the countryside, school buildings were not very different in form from the surrounding ordinary peasant cottages. Rural schools were therefore located almost exclusively in wooden buildings, often under a straw thatch roof. In many areas, namely in the eastern part of

\footnotetext{
${ }^{2}$ Kurier Warszawski, 1864, issue 168, p. 1015.

${ }^{3}$ BARANOWSKI, B.A., Szkolnictwo ludowe w Galicji w swym rozwoju liczebnym od roku 1868 do roku 1909 z uwzględnieniem stosunków higienicznych. Lviv 1911, p. 14.

${ }^{4}$ Ibidem.
} 
the country, school buildings were shanties with walls made of rolled straw or brushwood covered with clay. Not all schools had wooden floors, in some cases hardened clay was the only type of flooring.",

The implementation of the tasks pertaining to the construction of schools proposed by the NSC, as well as social and educational leaders, encountered a significant obstacle in the form of a lack of financial resources. Between 1873 and 1875, two legal acts were issued, aimed at dealing with these issues. The NSC "developed guidelines on the construction and furnishing of buildings housing public folk schools (approved by the Ministry of Education)," which was complemented with a regulation issued by the Ministry of Education on the 19th of July 1875, which included "provisions regarding the observance of sanitary regulations in public folk schools." In 1873, national school laws transferred oversight over the condition and furnishings of school buildings to local school councils, whose duties included, among other things, taking care of the condition of school buildings, as well as initiating new construction projects and constructing new facilities. Such a solution resulted in the fact that from that point onwards, the costs of construction and equipment of folk schools would be borne by local authorities (municipalities) and the surrounding areas belonging to landowners. "Although poorer municipalities were subsidised with national funds, the amount of which was left to the NSC's discretion, these subsidies were abysmal out of necessity, since the NSC itself did not have a large budget at its disposal, having loans strictly limited by the Sejm, in line with every year's budget ${ }^{6}$." Entrusting the responsibility for school buildings to local authorities often resulted in them showing little interest in difficult learning conditions. For example, in Drohobych, the functioning of the so-called Jurkiewiczówka folk school? was assessed as follows: "an old, low, wooden building, which was adapted several years ago from a residential house, with small and low wooden outbuildings built next to it $^{8}$." The location of the school was also criticised as, according to the article, it was situated "in a pork market, not covered by any tree that would give a shade in summer, which meant that during the hottest days the air inside just destroys the health of teachers and students alike ${ }^{9}$."

It was only under public pressure that anybody tried to solve and make up for the neglect. However, the main obstacle was still the lack of financial resources, lack of credit institutions and poverty in individual municipalities.

Despite the difficulties in the construction of school buildings, some towns and villages were trying to erect more buildings. For example, a school was built in Jarosław for approximately 800 children, but as it was stated in local press, the constructed building "was suitable for dozens, rather than hundreds of students ${ }^{10}$." The press note also points out

\footnotetext{
5 Ibidem, p. 14-15.

${ }^{6}$ BARANOWSKI, B. A., Szkolnictwo ludowe w Galicji, p. 17.

7 “Kronika", Kurier Drohobycki, 1889, issue 4, p. 3.

8 Ibidem.

9 Ibidem.

10 “Sprawa nie cierpiąca zwłoki”, Kurier Jarosławski, 1893, issue 7, p. 2.
} 
that the building was defective, as "in summer, each classroom is hot and muggy, while in winter the temperature inside was so low that children and teachers are exposed to the risk of catching a cold ${ }^{11}$." In fact, shoddy construction of school buildings was not a rare occurrence. Such cases were frequently reported in the press. In Rzeszów, a new school, which had not yet been commissioned, was described as follows: "the walls are chipping, the moisture is increasing and there are some justified fears whether it is going to be the end. From the very start, there was a lack of proper technical supervision during earthworks. The builders dug unnecessary cellars, where water collected up to the depth of 1.5 metres ${ }^{12}$."

The interest of the press in the issues pertaining to the construction and condition of folk schools grew significantly after 1894. Two years earlier, Mr Merunowicz, Member of Parliament, had submitted a proposal to the National Parliament to set up a permanent fund for loans to municipalities planning to build a school. "The Sejm could not take this request into account due to the fact that it would result in an excessive burden on the budget, but the final decision was made as follows: Mr Merunowicz's request for the creation of a loan fund for the construction of schools is to be transferred to the National Department with an order that it should examine whether the capital held by the school fund could be used to set up such a loan fund for rural municipalities, in cooperation with the $\mathrm{NSC}^{13}$." The project envisioned borrowing without interest. On the other hand, the national fund was obliged to pay interest on the capital taken for the construction. Subsequent issues of Krakus reported on the progress of work on the relevant legislation regarding the project. The NSC gave a positive opinion on the project, stating that "the amounts approved every year by the Sejm for grants and loans for the construction of schools in municipalities are not enough, because a large number of rural municipalities apply for loans and subsidies every year, and only a dozen or so municipalities may get a loan ${ }^{14}$." It was pointed out that municipalities, which were poor in general, could not afford investments such as new school buildings. It was also not possible to impose additional taxes on the local populace. "For this reason, rural municipalities can only hardly afford a school building that costs 1,000 to 3,000, and many schools cannot be opened due to the lack of a proper building. There are also many schools that have dedicated buildings in such a poor condition that it is impossible to teach in them. There are 209 municipalities in the country, where schools cannot be opened due to the lack of a proper building, and 855 municipalities have school buildings in dire need of a renovation ${ }^{15}$." The NSC requested that the loans should be repaid over a period of 10 years and that the repaid money should go to other villages and towns undertaking construction of a new school. It was also proposed that the school construction loan fund should operate for 10 years, that is until 1902. The Sejm established

\footnotetext{
${ }^{11}$ Ibidem.

12 “Kronika. Szkoła żeńska nowa”, Głos Rzeszowski, 1898, issue 14, p. 5.

13 “Sprawy krajowe, Fundusz pożyczkowy na budowę szkół”, Krakus, 1892, issue 35, p. 1.

14 "Fundusz pożyczkowy na budowę szkół”, Krakus, 1892, issue 41, p. 5.

15 Ibidem.
} 
the fund by a resolution on the 22nd of September 1892, which was finally approved by the emperor on the 27th of April 1894. The law introduced, among other things, a new proportional division of financial responsibility for folk education, divided between the municipality and landowners ${ }^{16}$.

On the one hand, the establishment of the loan fund in 1894 activated many municipalities and, most importantly, the NSC had an influence on the course of the construction process, which was subject to certain procedures. The school's set up had to be approved, it also had to take the principles of hygiene into consideration, and construction supervision was entrusted to experts appointed by the Council. However, it turned out that the technical supervision often failed to fulfil its duties and the school buildings were constructed improperly and without attention to detail. On the other hand, in many villages and towns, local authorities, after receiving help from their superiors, started to show less initiative than in the preceding years, when they had to take all decisions pertaining to the construction on their own.

At the same time, construction issues became a highly exposed topic of many press reports, in order to help and activate the local community.

In 1896, 512 students attended the six-grade folk school in Sambor, which was located in a parish building. The classrooms were so small that during calligraphy, drawing and writing classes, the teacher was forced - due to the lack of space - to "send several or even several dozen students at a time out of the classroom in succession. There is a lack suitable light, the hall is narrow. Latrines adjacent to the classrooms pollute the air, because with even the smallest gust of wind, the putrid air is pressed into classrooms, which sometimes have to hold as many as a hundred students. The school tables are so old and damaged that they do not meet hygiene requirements. Physical education, which is so crucial for children exists only on paper. The square in front of the school is a public place, with carts and people passing through at all times ${ }^{17}$." According to the author of the report, it was the former town councillors who were responsible for the terrible condition of the building, as they did not think about building a new place and creating proper conditions for local children to learn. Further in the report one can also read that in the field of school construction, Sambor "was overtaken by neighbouring towns: Jaworów, Sadowa Wisznia, Mościska, Staremiasto and even Turka. This is because these towns have constructed school buildings which are impressive, comfortable, fully compliant with hygienic requirements and which can serve as a model for councillors, who are more interested in housing government horses and troops stationed here than in the health of their own children ${ }^{18}$." The school council in Stryj took care of a school building as well. "The council's efforts led to the construction of an impressive building for the municipal school, which

${ }^{16}$ Until the implementation of the Act, i.e. until 1 January 1895, municipalities paid 9\%, while landowners paid 3\% of the maintenance costs of folk schools and teachers' salaries. "Kronika. Budowa nowych szkół", Zwiąek Chłopski, 1894, issue 6 p. 48; "Kronika", Zwiazek Chtopski, 1895, issue 13, p. 110.

17 "Korespondencja. z miast. Umieszczenie samborskich szkół ludowych”, Gazeta Samborska,1896, issue 5 , p. 3.

${ }^{18}$ Ibidem. 
can be counted among the prides of our city ${ }^{19}$." The Council also made sure to extend the building of the female school by adding a storey wing, moreover "the premises were secured to provide Sloyd education" in the Łany Dolne suburb ${ }^{20}$.

Let us now go back to Sambor, where local authorities were informed about the need to build a folk school. At the same time, it should be emphasised that the town authorities took care of constructing a new building for the local k. \& k. teachers' school, and the purchase of land in order to establish a plantation for the purposes of practical farming education at the aforementioned school. What is more, the municipal council decided to buy land for the construction of a boarding house for the school students. The author of the note makes a positive statement about this initiative, but with serious reservations, which end with a call for the construction of a folk school. "Let us first set aside a lot of land for the construction of a folk school, as for now our children have to learn in squalid nooks and crannies, which results in great damage to their health. Let us build that school first, and only then, when the funds allow for that, let us contribute to the purposes that are more desirable by our neighbouring district, rather than our own city ${ }^{21}$." In the opinion of the local journalist, the decision regarding building a school for future teachers was irresponsible, because it would serve not only local children, but also children from other areas. The local authorities had to make a difficult decision whether to build a folk school or a teachers' school, taking into account the financial capacity of the town. They ultimately decided on building a teachers' boarding school, taking into account the huge needs of education in Galicia, particularly regarding the organisation of folk schools for which teachers had to be educated first.

Construction and commissioning of a new school building was usually a reason for celebration for local children and adults alike. Głos Rzeszowski published the account of a consecration of a newly-built folk school in Łąk. The correspondent wrote: "This 30th of May will be remembered fondly by members of the local municipality, who, despite poverty, built a wonderful school with two classrooms out of bricks ${ }^{22}$. The ceremony was attended by a distinguished guest - Bishop of Przemyśl, Dr. Józef Sebastian Pelczar. The school was decorated with greenery and flags, and the bishop was greeted by mortar shots and a procession. At the end of the celebration, the Bishop "pointed out the need for a true Christian education, presenting its benefits, and encouraged parents to regularly send their children to study ${ }^{23}$."

The interest of the local community in local schools grew steadily. "The rural population understood the need and benefits of education, which led to building schools, but in

\footnotetext{
19 "Nowa Rada szkolna miejscowa w Stryju”, Gazeta Stryjska, 1893, issue 4, p. 1.

${ }^{20}$ Ibidem.

21 "Budowa bez odpowiedniego fundamentu", Gazeta Samborska, 1896, issue 1, p. 1.

${ }^{22}$ Correspondence of Gtos Rzeszowski, Łąka, the 2nd of June (Consecration of a school in Łąka), Głos Rzeszowski, 1899, issue 24, p. 2.

${ }^{23}$ Ibidem.
} 
many municipalities these buildings sit unused due to the lack of a teacher ${ }^{24}$." The local authorities, pressured by the public, with the significant contribution of the press, tried to solve the problem by undertaking school construction, while at the same time allocating as little money as possible for this purpose. Examples of such savings and their effects were recalled in the Szkoła magazine. Both the municipalities and landowners were obliged to provide land for the construction of a school. "Our municipalities primarily have pastures, and these are usually located so low that they are not even suitable for cereal cultivation ${ }^{25}$." Such land should be examined by a committee working on behalf of a District School Council, but the need to build a school, lack of additional funds for purchasing a suitable plot of land or the opinion that "the commission will not live in this school and their children will not attend it anyway"26 led the municipalities to start the planned construction in the belief that "things will work out somehow ${ }^{27}$." As a result, the newly constructed buildings were plagued with fungal growth, moisture, and continuous repairs, which required significant amounts of money every year. Often, the school buildings were built too small with the intention of saving money, but due to the growing number of students, it was necessary to locate some of the classrooms in places which "did not conform to any hygiene regulations" 28 , often at a significant distance from the main building, and leases often put a significant dent in the municipality's budget.

The NSC had been monitoring the needs of individual villages regarding the construction of school buildings. Among them were villages which were completely devoid of school buildings and, as a result, many children were deprived of education. In 1902 and 1903, the NSC decided to build one-classroom schools with the help of a subsidy from the national fund, in the following towns and villages: Roztocza (Dolina district), Porudno (Jaworów district), Wola Łużańska, Mszana and Smerekowiec (Gorlice district), Morsztyn (Stryj district), Konigsau (Drohobych district) ${ }^{29}$. In addition, the organisation planned to build two six-grade schools (male and female) in Powłoczyski (Skałat district) ${ }^{30}$. The implementation of these plans is in question, as the Rodzina i Szkoła magazine did not mention the opening of schools in the towns, where they were planned by the NSC.

Local press also noted some positive actions in favour of school construction. Several initiatives were registered in the Sambor district in $1906^{31}$. In Dorożow, a nine-metre wide lot of land was given over to the school by a resolution of the Municipal Council, which also allowed for the land to be attached to the school garden. In Bylice, the Municipal

\footnotetext{
24 "Szkoły ludowe pospolite a wydziałowe męskie", Głos Rzeszowski, 1901, issue 42, p. 2.

25 "Budynki szkolne", Szkoła, 1901, issue 1, p. 4.

${ }^{26}$ Ibidem.

${ }^{27}$ Ibidem.

28 Ibidem.

29 "Wiadomości potoczne", Rodzina i Szkoła, 1902, issue 2, p. 27; issue 8, p. 108-109.

30 “Wiadomości potoczne”, Rodzina i Szkoła, 1902, issue 8, p. 109.

31 “Z Samborskiej Rady Powiatowej”, Gazeta Samborska, 1906, issue 43, p. 1.
} 
Council undertook to cover the rest of the costs of building a brick school with two classrooms and a teacher's apartment using a non-refundable subsidy from the national school fund. In Siekierczyce, on the other hand, the Municipal Council undertook to build a oneclassroom school and to subsidise its construction in the event that it would not be covered by the NSC.

Journalists were also concerned about the arrangements of classrooms and the teachers' apartments. "Times have changed and the new school buildings stand out from their surroundings, because of their brick construction, as well as their size. However, the visitors are surprised when they realise that only their exterior has been changed, and that the old interior arrangement has been perfectly preserved ${ }^{32}$."

With increasing awareness of the population and therefore support for school building construction, often supported by appropriate press releases, local authorities tried to fulfil their obligations in this regard. However, this was not the case everywhere.

In Rzeszów, the City Council tried to solve the issue of the lack of school buildings in a way that was "an insult to even the most primitive rules of management ${ }^{33}$." During the June meeting of the council, a decision was made to add a floor to the existing building in Ruskawieś. Most probably, that initiative has never come to fruition. Soon, the NSC stated that education in municipal schools was taking place in violation of basic hygiene regulations and decided to close five classrooms in a number of city schools. At the same time, the Council stated that there were no rooms for three classes, demanding that the city deliver suitable rooms by September (1904) through the School District Council. At the next meeting of the city council, a proposal was made to purchase a building from the Rzeszów kehillah, the cost of which - including the necessary renovation - would significantly exceed the cost of erecting a new school building.

In subsequent years, however, the issue of the lack of school buildings remained unsolved in Rzeszów. At the beginning of 1906/1907, a decision was made to rent three rooms (at Lwowska 27), "where, after carrying out the necessary renovations, a threegrade Mickiewicz elementary school was established ${ }^{34}$." A press release indicates that "the newly built school in the south-western part of the city was built up to the roof in autumn and there is hope that the building will be commissioned after the summer holidays in 1907.

The construction of a few buildings, overcoming difficulties - including first and foremost the financial ones, as well as struggling to get past the local authorities, who seemed to ignore the issue, was not conducive to the inclusion of all children in education.

In 1907, the Sejm authorised the National Department to take out a loan of up to ten million krones for the construction of new folk schools. "The money shall be loaned through a gradual issuance of $4 \%$ bonds in the amounts established each year by the

\footnotetext{
32 "Plany wiejskich budynków szkolnych", Szkoła, 1901, issue 2, p. 12.

33 “Szkoły miejskie w Rzeszowie (Przyczynek do nędznej gospodarki)”, Głos Rzeszowski, 1904, issue 1, p. 1.

34 "Sprawozdanie miejskiego biura sanitarnego w Rzeszowie za r. 1906”, Głos Rzeszowski, 1907, issue 24, p. 2.
} 
National Department, on the basis of detailed dates provided to it by the NSC, for the construction of individual schools ${ }^{35}$." The construction of a significant number of school buildings, in line with all teaching and hygiene requirements, was launched thanks to the allocation of significant financial resources in 1908. This sum was used for non-refundable subsidies, and by December 1910 the fund had already been completely exhausted.

The amount of funding shows the great need to organise schools, many of which did not exist, because they did not have adequate buildings. The depletion of funds may also serve as evidence for the activity of rural communities, whose interest in having their own local schools was growing, which is why they were taking advantage of financial aid from the national fund.

The NSC had planned to erect 422 buildings with a total of 993 classrooms in 1908. This huge project, however, could not be carried out within one year, which is why "the National Department urged the NSC to submit a proposal for the construction of schools, the construction of which could be completed until the end of $1908^{36}$."

After 1908, the locations for the new schools were chosen with greater care, making it a condition that the construction could begin after a consultation with a physician. However, this ambitious intention remained but a postulate, as Galicia, despite many efforts of the NSC, did not have school doctors. Including government district physicians, who were tasked with hygienic supervision of schools (from time to time, due to the sheer amount of work), in the assessment process did not solve the issue of choosing a place to build a school in terms of hygiene.

"The choice of a suitable construction site is more difficult these days, as land prices have risen by several hundred percent in the last 30 years. For this reason, multi-storey school buildings are already being built more often. The increase in the land price is also a reason why it is not always possible to buy the most conveniently located plot of land for school construction ${ }^{37}$."

The example of Sambor is a perfect illustration of choosing cheap - and, as a result - unsuitable land. In 1908, after long debates, the idea of building a school was taken up, and a decision was made to use communal land on Przemyska Street, "opposite the military hospital, although this circumstance was a negative in the resolution ${ }^{38}$."

The author of the note published in Przyjaciel Ludu (1909) wrote: "it would be enough to show only a little good will, and the school could certainly be erected in the municipality. The lack of funds in the countryside cannot be used as excuse now, because the municipality is not obliged, as it used to be the case, to build schools using its own funds. Now it is the municipality's duty to donate 1 morgen of land to become a construction site ${ }^{39}$." Most probably, the author did not research the land belonging to the municipality, which

\footnotetext{
35 “Budowa szkół ludowych”, Przewodnik Oświatowy, 1907, p. 393-394.

36 “Budowa szkół ludowych”, Przewodnik Oświatowy, 1907, p. 394.

${ }^{37}$ BARANOWSKI, B.A., Szkolnictwo ludowe w Galicji..., p. 18.

38 “Z Rady miejskiej”, Gazeta Samborska, 1908, issue 24, p. 2.

39 HAŁADEJ, J., “O szkoły”, Przyjaciel Ludu, 1909, issue 16, p. 6.
} 
was very often located on the outskirts of the village, often on wetlands, which made it unsuitable for the construction of a school.

In 1911, funds for the construction of schools were exhausted. From 1908 to 1911, the NSC built 733 schools for the sum of 10 million kronor, "while at the same time reducing the amount allocated in national budgets from 400,000 to 200,000 kronor per year, and this amount was to be used solely for the renovations, expansions or restoration of existing schools ${ }^{40}$."

However, there still were 2,374 municipalities in 81 districts with no schools whatsoever. According to the anonymous author, more than 51 million kronor were needed to build such a number of schools ${ }^{41}$.

Given the economic conditions of Galicia, such a sum could not be allocated. The National Department submitted a request to the Sejm to take out a second loan of 10 million kronor for the construction of new folk schools in municipalities, which already had adequate land and suitable funds.

Municipalities that did not manage to build a school building before 1911 had to "wait two years or so for a new loan to be approved and impl emented by the Sejm ${ }^{42}$." Franciszek Krempa wrote: "Research shows that about 20 million more kronor will be needed to supply all the school districts with suitable school buildings ${ }^{43}$." In this situation, the NSC was to dispose funds from other sources dedicated for the construction of new schools. The author of the article warns municipalities against rash austerity decisions which, due to the lack of funds, would be imposed on local communities.

On 29 January 1912, the Budget Committee of the Sejm discussed a speech by J. Leo, who recommended that the National Department's proposal for an additional loan of ten million kronor for new school construction be approved. He also proposed that instead of granting non-refundable subsidies, interest-free loans should be given out. In the course of an (emotional) discussion, the Budget Committee finally approved the proposal for a loan of ten million kronor. An interesting motion put forward by Mr. Skołyszewski was also adopted: "The Sejm calls upon the NSC, in consultation with the National Council, to implement designs which correspond to the architecture in particular areas of the country in the place of the so-called model designs of folk schools, in consultation with the National Department ${ }^{44}$."

The idea of school building referring to the character of the region, was recalled during Podhale Congresses and the meetings of the Podhale Executive Committee ${ }^{45}$. It was emphasised that newly built schools are colourless and trite in their style. "The point is that it is important to keep everything beautiful and good what the past has produced in every

\footnotetext{
40 “Budowa szkół ludowych”, Przyjaciel Ludu, 1912, issue 7, p. 7.

41 Ibidem.

${ }^{42}$ KREMPA, F., “Budowa szkół”, Przyjaciel Ludu, 1911, issue 6, p. 5.

${ }^{43}$ Ibidem.

44 Ibidem.

45 “Szkoła na Podhalu”, Gazeta Podhalańska, 1913, issue 2, p. 4.
} 
field, as it is in the best interests of Polish culture ${ }^{46}$." In connection with the planned construction of a number of schools, the Executive Committee of the Third Podhale Congress, asked Andrzej Galica to prepare a design of a folk school in the Podhale style, together with the editorial staff of Gazeta Podhalańska. This design was published in Gazeta Podhalańska. However, there was no press release on whether this proposal has been implemented in practice.

On the one hand, it is possible to highlight the Galician authorities' efforts to solve the issue of folk school construction. The lack of adequate financial resources for this purpose has become a long-term problem. Despite the difficulties, "thanks to the 10-million fund, the number of sub-standard schools has decreased, but there are still so many of them, that many of such multi-million funds will have to be enacted before the entire country can be supplied with decent school buildings ${ }^{47}$."

Among the most frequent topics discussed by magazines was the issue of improper construction and, above all, failures to comply with hygiene requirements in schools. "Our school buildings in the villages are rank, as the requirements of school hygiene are not taken into account there; often their condition is such that they directly threaten the health of young people and the resident teacher ${ }^{48}$." As noted in the article, there are attempts to build brick schools in the villages. However, "due to the carelessness of the construction contractor, after some time they become damp, and as such they turn into habitats for a variety of fungi species. An example of this is the brick school in Kosienice, which has already been overgrown with mould and fungal growth to the highest degree ${ }^{49}$." Schools in Stroniowice, Borszowice, Borastycze, Bachów (Przemyśl district) were in a similarly disastrous state. In the case of a larger number of children applying for education, branches or so-called exposed classrooms were created, most often using a local reading room or a municipal office, which could accommodate from 10 to 15 children at most. There were also other drawbacks to the choice of such classrooms. It was noted that "in Hermanowice, there are portraits of Khmelnytsky and Zalizniak on the wall ${ }^{50}$." The article also discussed scandalous practices of locating the school branches. The detailed description of such a classroom in the village of Tarnawka reads as follows: "The classroom, transformed from a former detention centre into a lecture hall, is 3 metres long, 2.30 metres wide and 2.40 metres high, with windows placed at the height of three school tables. The church warden keeps his bedsheets under the teacher's pulpit, as he sleeps in the classroom. Next to the room, there is a closet, where they often keep the singing drunkards, much to the amusement young students ${ }^{51}$." The description of the local school branch shows that the local authorities did not care about the fate of the students. These activities lowered the

\footnotetext{
46 Ibidem.

${ }^{47}$ GALKIEWICZ, J., “O budowaniu szkół”, Przyjaciel Ludu, 1912, issue 8, p. 7.

48 “Kwestia budynków szkolnych”, Ziemia Przemyska, 1913, issue 2, p. 2.

49 Ibidem.

${ }^{50}$ Ibidem.

51 Ibidem.
} 
prestige of the school and teacher alike and stood in opposition to the elementary requirements of hygiene and culture.

The negative assessment of the condition of school buildings in Przemyśl District concerned not only the situation in rural areas, but also in the city of Przemyśl itself. "There is not a single school building in Przemyśl which would be in line with the latest achievements in school hygiene ${ }^{52}$," wrote the author of the article. He points out that there is moisture in the basements in the functioning schools in the city (H. Sienkiewicz school); the rooms are cramped and it is hard to breathe in there (Konarski school, John Cantius school, Mickiewicz school, Zasanie district school) and during breaks students are cramped in halls "filled with toilet fumes ${ }^{53}$." Continuing with the description of the negligence and faults in construction, the author recalls the example of the Queen Hedwig Female School, where all the classrooms have mould and the southern corner of the wall cracked from the roof to the foundation. The activities undertaken for the construction of a new school building in Przemyśl - in Błonie - were not implemented. The school was to be opened in 1911, then in 1912. A loan was taken out, but the money was spent on different things. In this "situation, "given the lack of school buildings, the postulate of mandatory education cannot be even taken seriously ${ }^{54}$."

The Folk School Society was a great supporter of the construction of schools, and the organisation supported such initiatives financially, mainly in "places where Polish identity is threatened ${ }^{55}$." In 1893, the Society built its second consecutive school in the "Masurian settlement of Hołosków, near the village of Głębokie in Nadvirna district, the birthplace of Franciszek Karpiński ${ }^{56}$.” In 1897, the FSL supported the Mariampil municipality with 800 kronor for the expansion of the school building, and a year later it also erected new schools in Dalejów at the cost of 19 thousand kronor and in Św. Stanisław for 8 thousand kronor $^{57}$. In 1904, the Society started construction works in Jeziorko at the cost of 6 thousand kronor. The FSS often organised public fundraisers for construction of new schools. For example, in 1906 a festival and a reception were organised, with 306 kronor raised for the construction of a school in Olszanik ${ }^{58}$.

Another important initiative of the FSS was the announcement of a competition for the school building in 1906. 20 projects were submitted in response ${ }^{59}$, which proves the interest of Galician society in constructing new buildings and in the combating illiteracy.

\footnotetext{
52 "Budynki szkolne a higiena", Ziemia Przemyska, 1913, issue 3, p. 2.

53 Ibidem.

${ }^{54}$ Ibidem.

55 “Refleksje ze zjazdu TSL”, Głos Rzeszowski, 1907, issue 29, p. 1.

56 "Kronika", Gazeta Stryjska, 1893, issue 5, p. 5.

57 W.O., "Powiat stanisławowski w cyfrach", Miesięcznik Towarzystwa Szkoty Ludowej, 1905, p. 145.

58 "Kronika", Gazeta Samborska, 1906, issue 26, p. 3 ff.

59 TSL. "Konkurs na budynek szkolny”, Goniec Jarosławski, 1906, issue 34, p. 3.
} 
The press also noted other initiatives, such as the activities of the Women's Circle in Kraków and Stanisławów, which financed the construction of a school or purchase of a plot of land (Zwardon, Wołosów) ${ }^{60}$.

During the period of autonomy in Galicia, the activities aimed at the construction of folk schools showed the huge problem faced by the NSC and lower ranks of school administration. The top-down decisions on these issues were often delayed or blocked by district and municipal administration. The belief of local communities that a school could be located "anywhere", in a crumbling cottage, shanty or a stable adapted for educational purposes often prevailed as well. An overwhelming majority of the existing schools did not offer children and teachers the necessary safety and health conditions, which were widely demanded by doctors at this point. The trend was adopted by construction contractors tasked with erecting the new buildings, who tried to appropriate the funds saved in this way, while the official supervision ignored their duties. The struggle for new schools, which was present in the press as well, made readers aware of the gravity of this issue. Numerous press articles recalled mostly negative examples, and by doing so they tried to raise awareness of local authorities and society about the issues concerning not only school construction, but also combating illiteracy and the postulate for implementation of compulsory schooling.

In the case of the Kingdom of Poland, the issue of the construction of elementary schools, which was addressed by the press, appears only at the beginning of the 20th century. Previously, occasional articles discussed the tragic technical condition of existing school buildings. Gazeta Radomska presented the situation of folk education in 1888 (in Radom province.) The author noted that "the efforts made by the local administration to increase the number of primary schools did not produce any positive results ${ }^{61}$." The reason for this fact was the refusal to finance the renovation of schools by the inhabitants of the province. The author does not mention the construction of new school buildings. As M. Brzeziński wrote in 1906, "in the near future we will face an enormous task of establishing at least 20,000 elementary schools in the Kingdom." ${ }^{26}$ Presentations of folk school plans and designs ${ }^{63}$ were the stimulus needed to start the construction of schools in reality. The Szkoła Polska magazine presented the design by Czesław Domaniewski, previously published in the Galician magazine Szkoła Ludowa, and also mentioned in the Miesięcznik

60 “Z ruchu kół”, Miesięcznik Towarzystwa Szkoty Ludowej, 1901, issue 6, p. 93; "Z Zarządu Głównego", Miesięcznik Towarzystwa Szkoty Ludowej, 1901, issue 7, p. 108.

${ }^{61}$ G.R., “Oświata ludu w guberni radomskiej”, Gazeta Radomska, 1888, issue 69, p. 1.

${ }^{62}$ BRZEZIŃSKI, M., "Projekt budynku szkoły wiejskiej”, Szkoła Polska, 1906, issue 4, p. 142; According to calculations carried out by S. Kopczyński, there should be 24000 schools, instead of the existing 4000 , KOPCZYŃSKI, S., "Stan spółczesny higieny szkolnej w Królestwie Polskim”, Sprawy Szkolne, 1908, issue 2, p. 92.

${ }^{63}$ BRZEZIŃSKI, M., "Projekt szkoły ludowej prywatnej dla Królestwa Polskiego", Miesięcznik Towarzystwa Szkoty Ludowej, 1905, issue 11, p. 433. 
Towarzystwa Szkoły Ludowej monthly ${ }^{64}$. A school building was being built in Słuyżewiec near Warsaw, not far from Ursynów, at the expense of the municipality and the owner," according to the design ${ }^{65}$.

The Kingdom of Poland also saw problems with the lack of funds for the construction of new school buildings. The aforementioned Gazeta Radomska mentioned Waśniewo (in Opatów district) where the school had to be shut down, because "the inhabitants of the municipality refused to contribute money for the school's maintenance ${ }^{66}$." A few years later, at a municipal meeting in Psary (in Kielce province) the inhabitants opposed spending funds for renovating the local building, stating that the poverty of the local population was the reason for the refusal. It was therefore decided to shut the school down for four years and "save up the contribution collected in the municipality for the maintenance of the school ${ }^{67}$." It was foreseen that the saved-up funds may not be enough to carry out the construction plan, so it was decided "to ask the government for the free grant of construction materials from the treasury forests, along with a subsidy in the amount of a third of the money required to build the school ${ }^{68}$."

Just like in Galicia, issues pertaining to hygiene at school were also often raised in the Kingdom as well. Stanisław Kopczyński, the author of an extensive article published in the Sprawy Szkolne magazine, wrote: "It is extremely difficult to properly illustrate the state of modern school hygiene in the Kingdom of Poland. The difficulty lies primarily in the abnormal state of the whole school system in Poland, which, ever since becoming a private Polish system two years ago, has not yet established proper foundations and is still struggling with material difficulties ${ }^{69}$." Until 1905, there was not a single building erected specially for educational purposes in Warsaw, which had one million residents at the time. Schools were located in rented buildings, often unsuitable for teaching purposes. Most of Kopczyński's text is devoted to the issue of school hygiene. Among other things, the author notes that: "The construction of folk schools with regard to the demands for hygiene progresses very slowly ${ }^{70}$." He considers the publishing of a number of school projects, taking into account the postulates of contemporary doctors, hygienists and architects, to be important for the construction campaign. He also lists the projects for the construction of single and two-grade schools from 1906 by C. Domaniewski and Z. Chrzanowski.

In the same year, Macierz Szkolna "announced a competition for a larger, privately funded folk school in Skulsko in the Kalisz province through the Warsaw Architects'

\footnotetext{
${ }^{64}$ DOBRZYŃSKI, E., "Projekt taniego domu dla szkółek ludowych w Królestwie Polskim”, Miesięcznik Towarzystwa Szkoły Ludowej, 1905, issue 12, p. 471.

65 BRZEZIŃSKI, M., Projekt budynku szkoty wiejskiej, p. 145.

${ }^{66}$ G.R., “Oświata ludu w guberni radomskiej”, Gazeta Radomska, 1888, issue 69, p. 1.

67 “Nowy budynek szkolny”, Gazeta Świąteczna, 1905, issue 1261, p. 2.

${ }^{68}$ Ibidem.

${ }^{69}$ KOPCZYŃSKI, S., “Stan spółczesny higieny szkolnej w Królestwie Polskim”, Sprawy Szkolne, 1908, issue 2, p. 91.

${ }^{70}$ Ibidem, p. 96.
} 
Circle, and in 1907 it also announced a competition for model designs - from the standpoints of hygiene and architecture - of one- and two-grade elementary schools ${ }^{71}$." The announcement was met with a response and about 70 works were submitted, among which more than a dozen received distinctions and awards. The goal of Macierz Szkolna was popularisation of construction designs among the public and encouragement of the construction of modern buildings.

In 1908, Józef Holewiński, who was a construction engineer, published a work entitled O budowie i urządzeniu szkót. Podręcznik praktyczny (Warsaw, 1908) [On the Construction and Furnishing of Schools. Practical Handbook]. In the introduction, the author wrote: "Clearly, raising the overall state of education is the most pressing need in the country. The lack of schools and ignorance of the masses that goes hand in hand with it are terrifying ${ }^{72}$." Holewiński points out the need to initiate a movement towards building schools in accordance with hygienic requirements. He was convinced that his handbook, which "contains the most important remarks and guidelines on building schools" "w3 will be useful for the whole Polish school system in the Kingdom of Poland. He argued that "the importance of a special school building for the normal running of classes at school is not to be underestimated. Cramped and uncomfortable classrooms, narrow and dark halls, lack of rooms for recreation, laboratory rooms, reading rooms, etc. are all things that, as we know, make education difficult ${ }^{74}$." Because, according to the author "school walls must speak both the language of an artist and mother tongue as much as the dignity of education $^{75}$."

Press articles on the construction of school buildings in the Kingdom of Poland started to appear at the beginning of the 20th century. Like in Galicia, the importance of erecting new buildings in accordance with technical and hygienic principles was also recognised in the Kingdom. Both in Galicia and the Kingdom of Poland, the close link between the conditions of education and the fight against illiteracy was emphasised. It was also pointed out that regarding construction, the strongest efforts should be directed to the countryside, where thousands of children were deprived of education due to the lack of proper classrooms.

The press, addressed to the readers in Galicia and the Kingdom of Poland, drew attention to important problems connected with construction. The society was made aware of the need to actively participate in this great project of building elementary and folk schools in accordance with modern architectural and hygienic standards.

\footnotetext{
${ }^{71}$ Ibidem.

${ }^{72}$ HOLEWIŃSKI, I., O budowie i urządzaniu szkót. Podręcznik praktyczny, Warsaw, 1908, p. 1.

${ }^{73}$ HOLEWIŃSKI, I., O budowie i urządzaniu szkót., p. 3.

${ }^{74}$ Z., "W sprawie gmachów szkolnych", Wychowanie w domu, 1911, vol. 2, p. 197.

75 Ibidem, p. 198.
} 


\section{Works cited}

BARANOWSKI, B.A., Szkolnictwo ludowe w Galicji w swym rozwoju liczebnym od roku 1868 do roku 1909 z uwzględnieniem stosunków higienicznych. Lviv, 1911.

BRZEZIŃSKI, M., "Projekt budynku szkoły wiejskiej”, Szkoła Polska 1906, issue 4.

BRZEZIŃSKI, M., "Projekt szkoły ludowej prywatnej dla Królestwa Polskiego", Miesięcznik Towarzystwa Szkoty Ludowej, 1905, issue 11.

"Budowa bez odpowiedniego fundamentu", Gazeta Samborska, 1896 issue 1.

"Budowa szkół ludowych", Przewodnik Oświatowy, 1907.

"Budowa szkół ludowych", Przewodnik Oświatowy, 1912, issue 7.

"Budynki szkolne a higiena", Ziemia Przemyska, 1913, issue 3.

"Budynki szkolne", Szkoła, 1901, issue 1.

DOBRZYŃSKI, E., "Projekt taniego domu dla szkółek ludowych w Królestwie Polskim", Miesięcznik Towarzystwa Szkoły Ludowej, 1905, issue 12.

"Fundusz pożyczkowy na budowę szkół", Krakus, 1892, issue 41.

G. R., "Oświata ludu w guberni radomskiej”, Gazeta Radomska, 1888, issue 69.

GALKIEWICZ, J., "O budowaniu szkół”, Przyjaciel Ludu, 1912, issue 8.

HAŁADEJ, J., "O szkoły”, Przyjaciel Ludu, 1909, issue 16.

HOLEWIŃSKI, I., O budowie i urządzaniu szkół. Podręcznik praktyczny, Warsaw, 1908.

KOPCZYŃSKI, S., "Stan spółczesny higieny szkolnej w Królestwie Polskim”, Sprawy Szkolne, 1908 , issue 2.

“Korespondencja. Z miast. Umieszczenie samborskich szkół ludowych”, Gazeta Samborska,1896, issue 5.

KREMPA, F., "Budowa szkół", Przyjaciel Ludu, 1911, issue 6.

"Kronika", Gazeta Stryjska, 1893, issue 5.

"Kronika", Kurier Drohobycki, 1889 issue 4.

"Kronika", Zwiazek Chtopski, 1895, issue 13.

"Kronika", Gazeta Samborska, 1906, issue 26.

"Kronika. Budowa nowych szkół", Związek Chłopski, 1894, issue 6.

"Kronika. Szkoła żeńska nowa", Głos Rzeszowski, 1898, issue 14.

KUCHARZEWSKI, J., Czasopiśmiennictwo polskie wieku XIX w Królestwie, na Litwie i Rusi oraz na emigracji, Warsaw, 1911.

"Kwestia budynków szkolnych", Ziemia Przemyska, 1913, issue 2.

"Nowa Rada szkolna miejscowa w Stryju", Gazeta Stryjska, 1893, issue 4.

"Nowy budynek szkolny", Gazeta Świateczna, 1905, issue 1261.

"Plany wiejskich budynków szkolnych", Szkoła, 1901, issue 2.

"Refleksje ze zjazdu TSL", Głos Rzeszowski, 1907, issue 29.

"Sprawa nie cierpiąca zwłoki”, Kurier Jarosławski, 1893, issue 7.

"Sprawozdanie miejskiego biura sanitarnego w Rzeszowie za r. 1906”, Głos Rzeszowski, 1907, issue 24.

"Sprawy krajowe, Fundusz pożyczkowy na budowę szkół”, Krakus, 1892, issue 35.

"Szkoła na Podhalu", Gazeta Podhalańska, 1913, issue 2.

"Szkoły ludowe pospolite a wydziałowe męskie", Głos Rzeszowski, 1901, issue 42.

"Szkoły miejskie w Rzeszowie (Przyczynek do nędznej gospodarki)", Głos Rzeszowski, 1904, issue 1.

TSL. "Konkurs na budynek szkolny", Goniec Jarosławski, 1906, issue 34.

W.O., "Powiat stanisławowski w cyfrach", Miesięcznik Towarzystwa Szkoły Ludowej, 1905.

"Wiadomości potoczne", Rodzina i Szkoła, 1902, issue 8.

"Wiadomości potoczne", Rodzina i Szkoła, 1902, issue 2. 
“Z Rady miejskiej”, Gazeta Samborska, 1908, issue 24.

"Z ruchu kół”, Miesięcznik Towarzystwa Szkoly Ludowej, 1901, issue 6.

"Z Samborskiej Rady Powiatowej”, Gazeta Samborska, 1906, issue 43.

"Z Zarządu Głównego", Miesięcznik Towarzystwa Szkoty Ludowej, 1901 issue 7.

Z., "W sprawie gmachów szkolnych", Wychowanie w domu, 1911, vol. 2.

Originally published in "Biuletyn Historii Wychowania", 2015, vol. 33, 41-56 
